\title{
EFFECT OF RAINFALL INTENSITY, SLOPE, LAND USE AND ANTECEDENT SOIL MOISTURE ON SOIL EROSION IN AN ARID ENVIRONMENT

\author{
F. M. Ziadat ${ }^{1, *}$, A. Y. Taimeh ${ }^{2}$
} \\ ${ }^{1}$ International Center for Agricultural Research in the Dry Areas (ICARDA), Amman, Jordan \\ ${ }^{2}$ Department of Land, Water and Environment, Faculty of Agriculture, University of Jordan, Amman, Jordan
}

Received: 27 June 2013; Revised: 4 August 2013; Accepted: 4 August 2013

\section{ABSTRACT}

Most climate change scenarios predict a significant increase in the frequency of high intensity rainfall events especially in the dry areas, which will increase runoff and soil erosion. Understanding the factors that control soil erosion is crucial to recommending appropriate measures to protect soils and reduce their vulnerability. The objective of this research was to investigate the effect of rainfall intensity, slope, land use and antecedent soil moisture on soil erosion and runoff. Twelve sites from Al-Muwaqqar watershed, Jordan, were selected to represent six slope angles- $1 \%, 2 \%$, $3 \%, 5 \%, 7 \%$ and $9 \%$. Two sites, one cultivated with barley and one as rangeland, were selected within each slope. Erosion was measured under three rainfall intensities $-3,5$ and $10 \mathrm{~mm} \mathrm{~h}^{-1}$ and three different antecedent soil moisture contents - dry, wet and very wet $t_{\overline{\mathbf{2}}}$ using rotating disk rainfall simulator. Regression equations indicated that rainfall intensity was the most important factor affecting soil erosion and that erosion could occur at a relatively small intensity on wet soils as a result of subsequent rainfall events. Soil erosion on cultivated land was primarily affected by moisture content, while on uncultivated land, it was mostly affected by slope steepness. Rainfall intensity, slope and antecedent moisture explained $84-89 \%$ and 59-66\% of the variation in runoff and soil loss, respectively. The results indicated the significant influence of cultivating the land on soil erosion. Copyright (C) 2013 John Wiley \& Sons, Ltd.

KEY WORDS: rainfall simulator; soil erodibility; surface crust; runoff; sediment concentration; Jordan

\section{INTRODUCTION}

Erosion poses a serious problem affecting the productivity of agricultural land (De Luis et al., 2010). The lack of information on the factors influencing erosion in the dry regions hinders the formulation of proper soil conservation plans. Rainfall in these regions is sporadic and varies spatially and temporally. Short but intensive thunderstorms of highly erosive rainfall usually take place early in the rainy season and at the end of the season. Although rainfall amounts are not considered high, soils in the arid areas suffer from high erosion rates because of intensive rain, steep slopes, sparse or absent vegetation cover (due to low rainfall and frequent drought), the presence of a strong surface crust and the traditional land management practices (Cerdà, 1999; GiménezMorera et al., 2010; Abu Hammad \& Tumeizi, 2012).

If no proper measures are taken to protect the soil, intensive agriculture to meet the increasing demand on food will accelerate soil erosion in these regions. Therefore, conservation measures are necessary to limit soil and water losses. Knowledge of the relationships between the factors contributing to erosion processes enables planners to suggest practical measures to reduce soil loss (Bisaro et al., 2013).

Among the factors that influence soil erosion and runoff are rainfall intensity, antecedent soil moisture content, slope steepness and land use/land cover. Rainfall intensity has been

\footnotetext{
* Correspondence to: F. M. Ziadat, International Center for Agricultural Research in the Dry Areas (ICARDA), P.O. Box 950764, Amman 11195, Jordan. E-mail: f.ziadat@cgiar.org
}

found to be among the most important factor related to runoff and erosion (Greer, 1971; Cerdà, 2002; Serrano-Muela et al., 2013). Rainfall intensity of more than $0 \cdot 8 \mathrm{in} \cdot \mathrm{h}^{-1}$, representing only $37 \%$ of the total rainfall, produces about $75 \%$ of the total soil loss (Greer, 1971). Research in an arid environment has indicated that a rainfall intensity of $1-2 \mathrm{~mm} \mathrm{~h}^{-1}$ results in runoff, while an intensity of more than $2 \mathrm{~mm} \mathrm{~h}^{-1}$ produces floods (Salameh et al., 1991). Ali et al. (2010) estimated the rainfall intensity threshold for runoff generation at about $4 \mathrm{~mm} \mathrm{~h}^{-1}$ in the arid areas of Syria.

The effect of antecedent soil water content on soil erosion is still a matter of debate, as opposing effects have been reported on aggregate breakdown and seal formation (Vermang et al., 2009). However, a significant effect of antecedent soil moisture on runoff generation has been reported. Wet soils double the runoff coefficient and shorten the time to runoff, compared with the same soils when dry (Li et al., 2011). Greater soil erosion was observed during the wet season in Spain (Cerdà, 2002). However, an opposite response due to a hydrophobic behavior of soil was reported by Martínez-Murillo and RuizSinoga (2007) and Gabarrón-Galeote et al. (2012).

The effect of slope steepness on soil loss is complex (Abrahams et al., 1996). Soil loss generally increases as the slope becomes steeper. The increase in soil loss is much more rapid than runoff (Wischmeier \& Smith, 1978). Erosion is believed to increase as a power function of the slope (Mah et al., 1992; Fu et al., 2011). Slope percentage accounts for $90 \%$ of the variation in the amount of soil detached and transported (Quansah, 1981). However, the effect of slope percentage on soil loss is believed to be influenced by an 
interaction with soil properties and surface conditions (Singer \& Blackard, 1982; Mah et al., 1992). The rate of increase in soil loss as slope increased is different for different soils (Singer \& Blackard, 1982). Other factors, such as rock fragment cover, soil surface conditions, crusts and litter indicated profound effects on runoff and soil erosion (Martínez-Murillo \& Ruiz-Sinoga, 2007; Martínez-Murillo \& Ruiz-Sinoga, 2010; Ruiz Sinoga et al., 2010; GabarrónGaleote et al., 2012).

The type of land use and land cover influence soil erosion. Soil erodibility was greater under agricultural land use compared with scrubland, with the difference becoming greater under arid environment, where aggregate stability of agricultural land is low (Cerdà, 2000). This means that cultivating the land under certain conditions might contribute to increasing soil erosion and runoff. Organic matter content controls the aggregate stability, and therefore, cultivating the land resulted in degradation of soil structure. Furthermore, the aggregate stability is expected to be reduced with decreasing rainfall as a result of climate change (Cerdà, 2000). The presence of vegetation enhanced infiltration and reduced surface runoff and erosion (Cerdà, 1999), and therefore, cultivating the land without providing protection measures might result in accelerated soil and water losses.

Runoff studies in the dry region are limited because they depend on natural rain and variability in intensity, drop size, drop energy, and spatial and temporal distribution. Rainfall simulation allows for the rapid and reproducible collection of data in laboratory and field experiments (Esteves et al., 2000). To obtain accurate runoff estimates using rainfall simulators, uniform rainfall with the correct reproduction of natural rainfall drop sizes and energies must be mimicked (Pérez-Latorre et al., 2010).
To obtain drops of the right size, while maintaining high velocities, high discharge nozzles are required (Mutchler \& Hermsmeier, 1965). However, the original intensities produced by these nozzles range from 600 to $1200 \mathrm{~mm} \mathrm{~h}^{-1}$. These application intensities were reduced to $1.5 \%$ of their original values by the intermittent application of a spray using a rotating disk with a radial slot cut placed below the nozzle (Morin et al., 1967). The trails showed that the rainfall simulator is capable of reflecting the soil and water loss that occurs under similar conditions of natural rainfall (Young \& Burwell, 1972). Using small plots under rainfall simulators is another consideration. However, recent researches reported that smaller plots can be used to reproduce the results from large-scale plots under rainfall simulations (Schindewolf \& Schmidt, 2012). Rainfall simulations are useful to understand the temporal and spatial variability of the soil erosion processes, but mostly provide qualitative information that allows comparing different conditions of soil, rainfall and environments (Martínez-Murillo et al., 2013).

The objective of this research was to study the effect of different rainfall intensities, slope, land use and antecedent soil moisture content on erosion and runoff using a rainfall simulator in an arid environment.

\section{MATERIALS AND METHODS}

The research was conducted in the Al-Muwaqqar watershed located $30 \mathrm{~km}$ southeast of Amman (Figure 1). The approxi- F1 mate area of the watershed is $70 \mathrm{~km}^{2}$. The watershed is located in an area representative of the arid-semiarid Mediterranean climate in Jordan. This area covers $13 \%$ of the total area of the country. Annual rainfall is $100-200 \mathrm{~mm}$, which falls between November and April. Storm events of high intensity usually occur during the rainy season, resulting in high soil

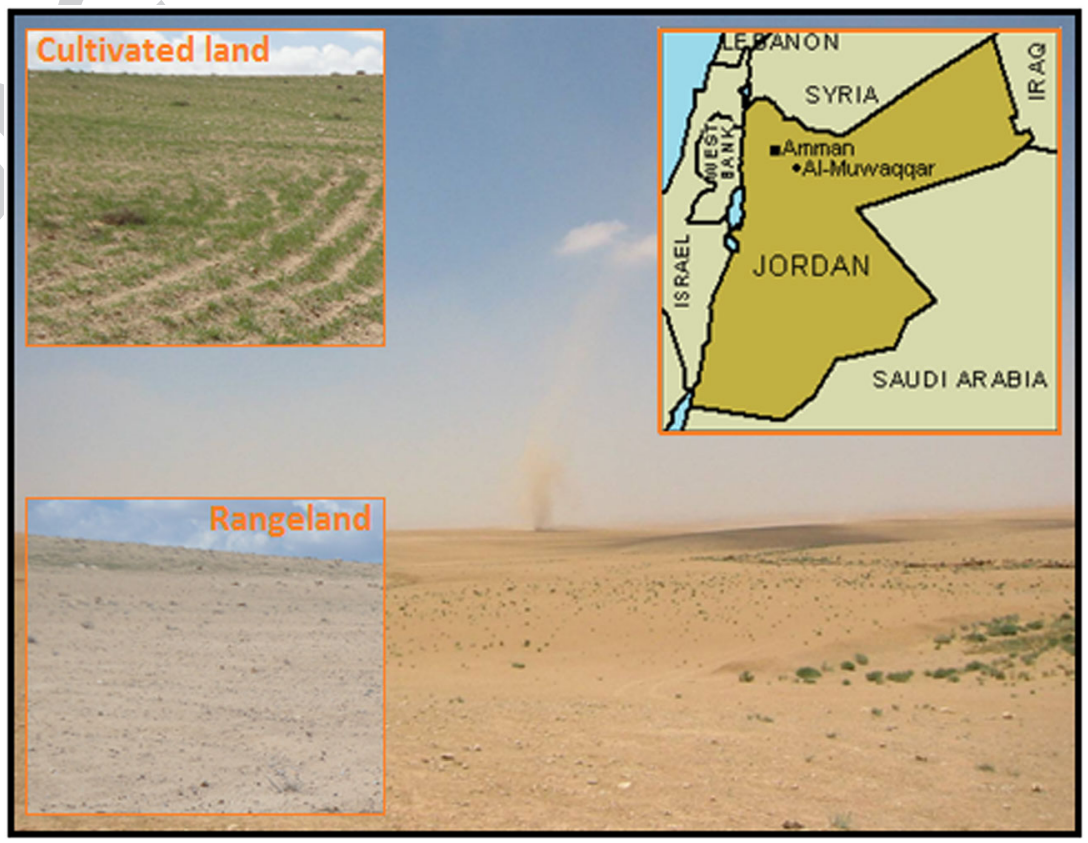

Figure 1. An overview and location of the study area within Jordan. This figure is available in colour online at wileyonlinelibrary.com/journal/ldr. 
loss. Generally, the area is characterized by very sparse vegetation cover, and soils with a high silt content in the surface layers, low organic content, strong surface crust and weak aggregation. Sheet and rill erosion are dominant over other types of erosion (Taimeh, 1989).

Soils for the rainfall simulator analysis were selected from 12 sites representing dominant slopes, land cover and soil types. Slope angles of $1 \%, 2 \%, 3 \%, 5 \%, 7 \%$ and $9 \%$ were selected. Soils were taken from two sites for each slope, one from uncultivated (natural rangeland) and one from cultivated (barley) land (Figure 1). These represent the dominant two land uses in the study area. The soils were taken during the dry season. The uncultivated soils represent the natural rangelands without any tillage operations, while cultivated land was tilled and already sown with barley before the commence of the rainy season. Undisturbed soils were settled in the test trays $(25 \times 25 \mathrm{~cm})$ in the field. The trays were equipped with a triangular-shaped runoff collector. The end of the collector was connected to a flexible hose leading to a collection bottle. Soils were laid over a perforated piece of metal to allow for the free drainage of water.

A rotating disk rainfall simulator was used to simulate rainstorms. Soils were subjected to rainfall intensities of 3 , 5 and $10 \mathrm{~mm} \mathrm{~h}^{-1}$. These intensities represent the dominant minimum and maximum rain intensities in that region (Taimeh, 1989). Distilled water was used $\left(\mathrm{EC}=0.05 \mathrm{dS} \mathrm{m}^{-1}\right)$. The actual simulated rainfall intensities deviated from the pre-selected intensities as follows: 8.2 to 12.2 designed as $10 \mathrm{~mm} \mathrm{~h}^{-1} ; 3.9$ to 6.6 designed as $5 \mathrm{~mm} \mathrm{~h}^{-1}$; and 2.4 to $4 \cdot 3$ designed as $3 \mathrm{~mm} \mathrm{~h}^{-1}$.

The three intensities were applied to all soils in three runs, representing three different antecedent soil moisture contents. These runs were as follows:

1. Dry run, applied to soil at air dry moisture status, for $60 \mathrm{~min}$.

2. Wet run, applied $24 \mathrm{~h}$ after the dry run, for $30 \mathrm{~min}$.

3. Very wet run, applied $30 \mathrm{~min}$ after the wet run, for $30 \mathrm{~min}$.

The experiment was arranged in a factorial design, with three factors (slope, rainfall intensity and antecedent soil moisture levels) and three replicates. Soil moisture content was measured before each run by a gravimetric method
(Gardner, 1986) using a small soil sample taken with a metal core (1 cm diameter). Rainfall intensity was measured in each run by metal cans $(7.5 \mathrm{~cm}$ diameter $)$ placed around the trays. Distribution uniformity of simulated rainfall was evaluated several times, using a duration of $30 \mathrm{~min}$, with cans spaced $5 \mathrm{~cm}$ apart. Distribution uniformity of the simulated storms, measured at the location of the test trays, was $84 \%$ (based on nine measurements for the three intensities). Many researchers have reported a comparable uniformity and consider it to be acceptable (Morin et al., 1967; Mah et al., 1992). Runoff volume was collected and measured every $10 \mathrm{~min}$ after runoff was observed. Each runoff volume was used to determine sediment concentration by drying the soil at $105^{\circ} \mathrm{C}$. The data were analyzed to calculate the effect of individual factors on soil erosion and runoff as well as the interaction using analysis of variance. The runoff volume and sediment concentration at $10 \mathrm{~min}$ intervals were plotted against time to examine the rate of changes in these parameters.

\section{RESULTS AND DISCUSSION}

Analysis of the data from both cultivated and uncultivated soils indicated the significant effect of slope, rainfall intensity and antecedent soil moisture content on soil loss, sediment concentration, runoff coefficient and time to runoff. The results also indicated significant interaction between these factors on soil erosion. Therefore, the discussion will focus on the effect of each factor separately and the relative effect of all factors.

\section{Effect of Slope and Soil Properties}

Topography is a key factor in controlling soil processes and characteristics under various conditions (Asadi et al., 2012). Soil loss generally increased as slope steepness increased on both cultivated and uncultivated soils. However, the effect of slope was more obvious on uncultivated soils (Table I). T1 This is attributed to low soil surface roughness for the uncultivated (natural) land. Cultivated soils are usually subject to annual disturbance by tillage and farming operations; therefore, they have high surface roughness.

Regression analysis was used to examine the relationship between soil erosion measurements and soil properties (soil texture, organic matter, calcium carbonate, infiltration rate,

Table I. Effect of slope steepness on soil erosion parameters for cultivated and uncultivated soils

\begin{tabular}{|c|c|c|c|c|c|c|c|c|}
\hline \multirow[b]{2}{*}{ Slope \% } & \multicolumn{2}{|c|}{ Runoff coefficient } & \multicolumn{2}{|c|}{ Sediment concentration $\left(\mathrm{g} \mathrm{L}^{-1}\right)$} & \multicolumn{2}{|c|}{ Soil loss $\left(\mathrm{kg} \mathrm{ha}^{-1} \mathrm{~h}^{-1}\right)^{*}$} & \multicolumn{2}{|c|}{ Time to start runoff (min) } \\
\hline & Cultivated & Uncultivated & Cultivated & Uncultivated & Cultivated & Uncultivated & Cultivated & Uncultivated \\
\hline 1 & $0.21 \mathrm{c}$ & $0 \cdot 29 \mathrm{~d}$ & $0.28 \mathrm{c}$ & $0 \cdot 16 \mathrm{e}$ & $103 \mathrm{c}$ & $52 \mathrm{f}$ & $23 \mathrm{~b}$ & $18 \mathrm{ab}$ \\
\hline 2 & $0 \cdot 16 \mathrm{~d}$ & $0 \cdot 30 \mathrm{~d}$ & $0 \cdot 15 \mathrm{~d}$ & $0 \cdot 30 \mathrm{de}$ & $63 \mathrm{~d}$ & $103 \mathrm{e}$ & $26 \mathrm{a}$ & $18 \mathrm{ab}$ \\
\hline 3 & $0.25 \mathrm{~b}$ & $0.32 \mathrm{c}$ & $0.33 \mathrm{bc}$ & $0.46 \mathrm{~d}$ & $131 \mathrm{bc}$ & $162 \mathrm{~d}$ & $22 \mathrm{bc}$ & $18 \mathrm{ab}$ \\
\hline 5 & $0 \cdot 26 \mathrm{~b}$ & $0.35 \mathrm{bc}$ & $0 \cdot 35 \mathrm{bc}$ & $0.68 \mathrm{c}$ & $140 \mathrm{bc}$ & $209 \mathrm{c}$ & $20 \mathrm{c}$ & $17 \mathrm{bc}$ \\
\hline 7 & $0 \cdot 32 \mathrm{a}$ & $0.37 \mathrm{~b}$ & $0.50 \mathrm{a}$ & $1.09 \mathrm{~b}$ & $181 \mathrm{a}$ & $360 \mathrm{~b}$ & $19 \mathrm{~d}$ & $17 \mathrm{bc}$ \\
\hline 9 & $0 \cdot 34 \mathrm{a}$ & $0 \cdot 41 \mathrm{a}$ & $0 \cdot 41 \mathrm{ab}$ & $1.28 \mathrm{a}$ & $168 \mathrm{ab}$ & $445 \mathrm{a}$ & $20 \mathrm{c}$ & $17 \mathrm{bc}$ \\
\hline
\end{tabular}

Means followed by the same letter in the same column are not significantly different $(\alpha=0 \cdot 05)$. 
soil erodibility, mean weight diameter, $\mathrm{pH}$ and electrical conductivity). The results indicated very low regression coefficients $\left(R^{2}<0 \cdot 10\right)$ between soil erosion and soil properties. This means that the variability in soil erosion on cultivated soils cannot be explained by the variation in soil properties alone in this study area. Similar results were obtained by Singer Blackard (1982), who reported that no physical or chemical property of soil appeared to exhibit a strong correlation with soil loss for different soils from the dry regions. Abrahams et al. (1996) indicated similar results regarding the relationship between slope steepness and soil loss.

Variation in soil erosion in an arid environment could be attributed to the interaction between several soil properties. Soils in this region are characterized by a high tendency to form a crust on wetting because of low organic matter percentages and high silt contents. Researchers reported that differences in runoff volumes among different soils could be attributed to differences in the rate at which seals are formed, not to the variation in a single soil property (Ramos \& Martínez-Casasnovas, 2010).

\section{Effect of Rainfall Intensity}

Soil loss and all other erosion measurements, including runoff, increased significantly as rainfall intensity increased T2 for both cultivated and uncultivated soils (Table II). High soil losses resulting from a very small increment in rainfall intensity is indicative of the susceptibility of these soils to erosion. However, soil erodibility prediction, expressed as K-values (Ziadat, 1995), did not suggest high susceptibility to erosion. Many researchers have reported that the measured K-values for a soil with surface crust are much higher than predicted K-values (Singer et al., 1982; Vermang et al., 2009). Singer et al. (1982) recommended an increase of $20 \%$ in the predicted K-value to account for the effect of soil dispersion in soils that tend to form a crust. Vermang et al. (2009) suggested that antecedent soil moisture content should be considered as an additional variable to assess soil erodibility. Furthermore, double-ring infiltrometers were used to measure the basic infiltration rate and to estimate the soil permeability. Cerdà (2002) indicated that the infiltration rates measured using double-ring infiltrometers were not successfully linked with high erosion rates, and therefore, the use of these was not recommended in the dry area of Spain.
Data for soils taken from cultivated land showed no runoff at an intensity of $3 \mathrm{~mm} \mathrm{~h}^{-1}$. On the other hand, the increase in soil loss as the intensity increased from 5 to $10 \mathrm{~mm} \mathrm{~h}^{-1}$ was much lower than the increase that resulted as the intensity increased from 3 to $5 \mathrm{~mm} \mathrm{~h}^{-1}$ (48 compared with $173 \mathrm{~kg} \mathrm{ha}^{-1} \mathrm{~h}^{-1}$ ). This may be attributed to the effect of the formation of a surface crust that reduces infiltration and causes runoff and soil loss at a rainfall intensity of $5 \mathrm{~mm} \mathrm{~h}^{-1}$. Researches have reported a reduction in sediment concentration as a result of crust formation (Bradford et al., 1987).

\section{Effect of Antecedent Soil Moisture Content}

Soil loss from both cultivated and uncultivated soil was significantly higher in the wet and very wet run compared with the dry run (Table III). This large difference existed T3 despite the fact that the wet and very wet runs $(30 \mathrm{~min})$ were shorter than the dry run $(60 \mathrm{~min})$. The higher soil loss for the wet and very wet runs is attributed to the significantly higher antecedent soil moisture content. The hydraulic gradient decreases as soil moisture content increases (Bradford et al., 1987). The reduction in the infiltration rate causes higher runoff and consequently higher soil loss. This means that successive rainstorms that occur within a short period might cause high runoff and soil loss in this arid environment. Similar results were reported by Murphree Mutchler (1981), who reported an increase in soil loss for a second series of rainfall application and attributed this to a higher antecedent soil moisture content. Similarly, Peng and Wang (2012) indicated that large runoff and soil loss could be produced from rainfall events with high antecedent precipitations.

Another factor that may have caused an increase in soil loss in the wet and very wet run is the formation of a crust on the surface of the cultivated soil after $60 \mathrm{~min}$ of rainfall during the dry run. The influence of crust formation is evident from the longer time to start runoff in the dry run that was about 2.5 times longer than in the wet run (Table III).

The results also indicated a significant increase in soil loss between the wet and dry runs for both cultivated and uncultivated soils, and between very wet and wet runs for uncultivated soils only (Table III). This is because uncultivated land is not subjected to annual tillage, and the soil surface is covered with crust. Similar findings were reported in eastern Spain, where various management

Table II. Effect of rainfall intensity on soil erosion parameters for cultivated and uncultivated soils

\begin{tabular}{|c|c|c|c|c|c|}
\hline Land use & $\begin{array}{l}\text { Rainfall intensity } \\
\qquad\left(\mathrm{mm} \mathrm{h}^{-1}\right)\end{array}$ & $\begin{array}{l}\text { Runoff } \\
\text { coefficient }\end{array}$ & $\begin{array}{c}\text { Sediment } \\
\text { concentration }\left(\mathrm{g} \mathrm{L}^{-1}\right)\end{array}$ & $\begin{array}{c}\text { Soil loss* } \\
\left(\mathrm{kg} \mathrm{ha}^{-1} \mathrm{~h}^{-1}\right)\end{array}$ & $\begin{array}{l}\text { Time to start } \\
\text { runoff (min) }\end{array}$ \\
\hline \multirow[t]{3}{*}{ Cultivated land } & 3 & $0.00 \mathrm{c}$ & $0.00 \mathrm{c}$ & $0 \mathrm{c}$ & $0 \mathrm{c}$ \\
\hline & 5 & $0.37 \mathrm{~b}$ & $0.43 \mathrm{~b}$ & $173 \mathrm{~b}$ & $14 \mathrm{a}$ \\
\hline & 10 & $0.40 \mathrm{a}$ & $0.57 \mathrm{a}$ & $221 \mathrm{a}$ & $11 \mathrm{~b}$ \\
\hline \multirow{3}{*}{ Uncultivated land } & 3 & $0.01 \mathrm{c}$ & $0.01 \mathrm{c}$ & $8 \mathrm{c}$ & $39 a$ \\
\hline & 5 & $0.49 \mathrm{~b}$ & $0.68 \mathrm{~b}$ & $229 \mathrm{~b}$ & $7 \mathrm{~b}$ \\
\hline & 10 & $0.52 \mathrm{a}$ & $1.30 \mathrm{a}$ & $430 \mathrm{a}$ & $6 \mathrm{c}$ \\
\hline
\end{tabular}

Means followed by the same letter in the same column are not significantly different $(\alpha=0 \cdot 05)$. 
Table III. Effect of antecedent soil moisture on soil erosion parameters for cultivated an

\begin{tabular}{|c|c|c|c|c|c|c|}
\hline Land use & $\begin{array}{l}\text { Moisture } \\
\text { level }\end{array}$ & $\begin{array}{l}\text { Runoff } \\
\text { coefficient }\end{array}$ & $\begin{array}{c}\text { Sediment } \\
\text { concentration }\left(\mathrm{g} \mathrm{L}^{-1}\right)\end{array}$ & $\begin{array}{c}\text { Soil loss* } \\
\left(\mathrm{kg} \mathrm{ha}^{-1} \mathrm{~h}^{-1}\right)\end{array}$ & $\begin{array}{l}\text { Time to start } \\
\text { runoff (min) }\end{array}$ & $\begin{array}{l}\text { Antecedent soil } \\
\text { moisture }\left(\mathrm{Pw}_{\mathrm{w}} \%\right)\end{array}$ \\
\hline Cultivated & Dry & $0.10 \mathrm{c}$ & $0.20 \mathrm{c}$ & $67 \mathrm{~b}$ & $37 \mathrm{a}$ & $5 \cdot 5 \mathrm{c}$ \\
\hline \multirow[t]{2}{*}{ land } & Wet & $0.27 \mathrm{~b}$ & $0.34 \mathrm{~b}$ & $152 \mathrm{a}$ & $15 \mathrm{~b}$ & $17 \cdot 6 \mathrm{~b}$ \\
\hline & Very wet & $0.40 \mathrm{a}$ & $0.45 \mathrm{a}$ & $173 \mathrm{a}$ & $12 \mathrm{c}$ & $23 \cdot 0 \mathrm{a}$ \\
\hline Uncultivated & Dry & $0.23 \mathrm{c}$ & $0.52 \mathrm{~b}$ & $110 \mathrm{c}$ & $27 \mathrm{a}$ & $5 \cdot 7 \mathrm{c}$ \\
\hline \multirow[t]{2}{*}{ land } & Wet & $0.35 \mathrm{~b}$ & $0.52 \mathrm{~b}$ & $214 \mathrm{~b}$ & $14 \mathrm{~b}$ & $15 \cdot 8 \mathrm{~b}$ \\
\hline & Very wet & $0.45 \mathrm{a}$ & $0.95 \mathrm{a}$ & $342 \mathrm{a}$ & $11 \mathrm{c}$ & $21.9 \mathrm{a}$ \\
\hline
\end{tabular}

Means followed by the same letter in the same column are not significantly different $(\alpha=0 \cdot 05)$.

practices lead to the problem of crust development (GarcíaOrenes et al., 2010; García-Orenes et al., 2012). In one hand, this will increase runoff due to low infiltration rate, and on the other hand, this will increase detachability and transportability of soil particles, which results in a marked increase in soil loss as rain continues to fall on these lands. In the cultivated soils, the progressive development of crust reduces the detachability of soil particles, resulting in a nonsignificant increase in soil loss in the very wet run compared with the wet run, although runoff is significantly higher. Vermang et al. (2009) reported that soil erodibility decreased with increasing antecedent soil moisture content, and Truman et al. (2011) reported an increase in runoff but a reduction in sediments as a result of increasing antecedent water content in cultivated soils. Similarly, Defersha and Melesse (2012) reported that sediment concentrations were higher for an initially air dry surface $\left(24.3 \mathrm{~g} \mathrm{~L}^{-1}\right)$ compared with those from an initially wet surface $\left(18 \cdot 7 \mathrm{gL}^{-1}\right)$.

\section{Relative Effect of Slope, Rainfall Intensity and Antecedent} Soil Moisture Content on Soil Erosion

Regression analysis was used to examine the relative contribution of slope steepness, rainfall intensity and antecedent

T4 soil moisture content on soil erosion and runoff (Table IV). The results indicated that slope, rainfall intensity and antecedent soil moisture content have a greater contribution in explaining the variations in runoff compared with soil loss. The three factors explained $84-89 \%$ of the variations in runoff, but only $59-66 \%$ of the variations in soil loss. This suggests that other factors are required to explain the variation in soil loss. It may be postulated that crust formation is one of these factors because there is significant correlation between the final infiltration rate (last 10 min of the very wet run) and some soil properties such as silt content $(R=0 \cdot 72)$, organic matter $(R=0.48)$, soil erodibility factor $(R=0.58)$, mean weight diameter $(R=-0.58)$ and soil salinity $(R=-0.76)$.

The computed standardized regression equations (Steel et al., 1996) indicated that rainfall intensity generally had the highest contribution to soil loss and runoff for both cultivated and uncultivated soils (Table IV). Many researchers have reported that rainfall intensity is a very important factor affecting soil erosion (Quansah, 1981; Martínez-Murillo et al., 2013). The large increase in soil loss as a result of the small increase in rainfall intensity, particularly in this arid environment, was discussed earlier.

The relative contribution of slope and antecedent moisture on soil loss and runoff was interchangeable between cultivated and uncultivated soils. The contribution of the three factors to soil loss and runoff for cultivated soil can be arranged, according to the standardized regression coefficients, in the following order: rainfall intensity $>$ antecedent moisture $>$ slope steepness. For uncultivated soil, it was rainfall intensity $>$ slope $>$ antecedent moisture for soil loss and rainfall intensity $>$ slope for runoff.

Slope contribution was higher to soil loss and runoff in uncultivated than in cultivated soils. Soil erosion on the crusted surface of uncultivated soil seems to be largely affected by slope, while in cultivated soils, it seems to depend on other factors, such as antecedent soil moisture content. Surface condition, mainly surface roughness induced by cultivation, changes rapidly as more rain falls. Aggregate stability in this area is low; therefore, the soil aggregates collapse quickly, forming surface sealing, which

Table IV. The computed equations to predict some erosion variables for cultivated and uncultivated (natural) soils

\begin{tabular}{|c|c|c|c|}
\hline Land use & Erosion variable & Computed equations $^{\mathrm{a}}$ & $R^{2}$ \\
\hline \multirow[t]{2}{*}{ Cultivated land } & Soil loss ${ }^{* * *}\left(\mathrm{~kg} \mathrm{ha}^{-1} \mathrm{~h}^{-1}\right)$ & $\begin{array}{l}10\left(-16 \cdot 62+0.36 \mathbf{I}^{1.1}+0 \cdot 22 \mathbf{S}^{1 \cdot 1}+11 \cdot 12 \mathbf{A S M C}^{0.1}\right) \\
0.62 \mathbf{I}^{1 \cdot 1}+0.33 \mathbf{S}+0.38 \mathbf{A S M C}^{\mathrm{b}}\end{array}$ & 0.66 \\
\hline & Runoff volume (mL) & $\begin{array}{l}-233 \cdot 88+94.65 \mathbf{I}^{0.5}+4.27 \mathbf{S}^{1 \cdot 2}+4 \cdot 19 \mathbf{A S M C}^{0.9} \\
0.80 \mathbf{I}^{0.5}+0.27 \mathbf{S}+0.31 \mathbf{A S M C}^{\mathrm{b}}\end{array}$ & $0 \cdot 84$ \\
\hline \multirow[t]{2}{*}{ Uncultivated land } & Soil loss $\left(\mathrm{kg} \mathrm{ha}^{-1} \mathrm{~h}^{-1}\right)$ & $\begin{array}{l}10\left(-9 \cdot 12+0 \cdot 94 \mathbf{I}^{1 \cdot 1}+0 \cdot 49 \mathbf{S}^{1 \cdot 3}+0 \cdot 01 \mathbf{A S M C}^{1 \cdot 9}\right) \\
0.60 \mathbf{I}^{1 \cdot 1}+0.43 \mathbf{S}+0.24 \mathbf{A S M C}^{\mathrm{b}}\end{array}$ & $0 \cdot 59$ \\
\hline & Runoff volume (mL) & $\begin{array}{l}-512 \cdot 38+212 \cdot 69 \mathbf{I}^{0.4}+161.98 \mathbf{S}^{0.1} \\
0.93 \mathbf{I}^{0.4}+0 \cdot 15 \mathbf{S}^{\mathrm{b}}\end{array}$ & $0 \cdot 89$ \\
\hline
\end{tabular}

${ }^{\mathrm{a}} \mathrm{I}$, rainfall intensity $\left(\mathrm{mm} \mathrm{h}^{-1}\right) ; \mathrm{S}$, slope steepness $(\%)$; ASMC, antecedent soil moisture content $(\mathrm{Pw} \%)$; all equations are significant $(\alpha=0 \cdot 05)$.

${ }^{\mathrm{b}}$ Standardized regression equations. 
reduces the infiltration rate, increases particle detachment and increases runoff.

\section{Soil Erosion from Cultivated and Uncultivated Soils}

Soil loss and runoff were higher for uncultivated soils compared with cultivated soils (Tables I-III). The higher runoff from uncultivated soils compared with cultivated soils was mainly due to the soil surface condition. The soil surface of the uncultivated soil was very compacted and smooth (lower porosity and roughness), which reduces the infiltration rate and facilitates runoff. On the other hand, the soil surface of the cultivated soil, especially before rainfall, has higher porosity and higher surface random roughness than the uncultivated soil. This may be responsible for the higher infiltration and higher water retention capacity, thus less runoff. However, after $60 \mathrm{~min}$ of rainfall application on cultivated soils, the surface crust started to develop, causing higher runoff in the subsequent runs. García-Orenes et al. (2009) indicated that because of high rates of soil and water losses on cultivated land, management practices were not sustainable, while Cerdà and Doerr (2007) concluded that the ground cover is a very important determinant of soil erodibility. Barbera et al. (2012) indicated that land cultivation induce a long-term degradation of the soil that results in an increase in soil losses and higher runoff rates. Soil erodibility was greater under agricultural land use compared with scrubland, with greater differences in the arid sites (Cerdà, 2000). Many researches demonstrated how agriculture and various management practices, directly or indirectly, might contribute to more degraded soils and consequently high erosion rates (Wang et al., 2011; Yimer \& Abdelkadir, 2011; Kocyigit \& Demirci, 2012; Stavi et al., 2012). More explanation of the high erosion rate on cultivated land, especially as more rain is falling on the surface, will follow in subsequent sections.
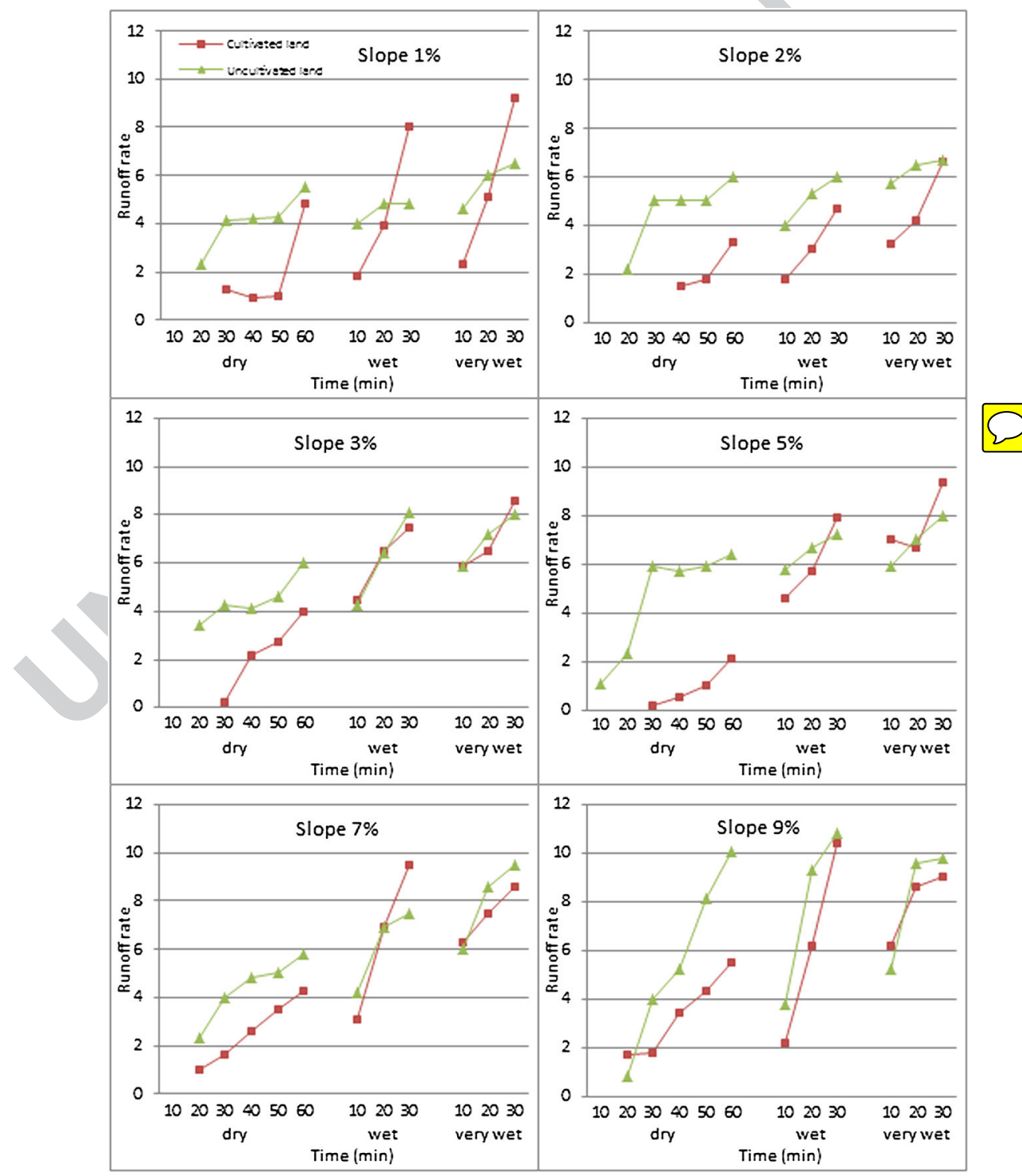

Figure 2. Runoff rate $\left(\mathrm{mm} \mathrm{h}^{-1}\right)$ measured each $10 \mathrm{~min}$ under a rainfall intensity of $10 \mathrm{~mm} \mathrm{~h}^{-1}$. This figure is available in colour online at wileyonlinelibrary. $\mathrm{com} /$ journal/ldr. 


\section{Rate of Change in Runoff and Soil Loss}

Runoff volume and sediment concentrations were measured every 10 min during the three runs to assess the change in or rainfall intensity has negligible effect on the rate of increase in runoff volume with time. The most important differences in the rate of increment of runoff were found between uncultivated and cultivated soils, and between different antecedent soil moisture levels (Figure 2).

The rate of runoff for uncultivated soils increased during the three runs until it reached relatively stable values at the end of the very wet run. This suggests that the infiltration rate in the uncultivated soils may reach a steady-state rate after this period. This again may be attributed to the rather stable soil surface of the uncultivated soils. Because changes in the soil surface condition, as a result of rainfall application, are minor, hydraulic gradient could be the primary

factor in controlling the infiltration rate. This was not the case for the cultivated soils where the rate of runoff increased continuously during the dry, wet and very wet runs and never reached constant values similar to those obtained with the uncultivated soils.

The rate of increase in soil loss was, to a large extent, similar to the runoff rate during the dry and wet runs (Figure 3). The rate of soil loss for the uncultivated soils reached a maximum value during the wet run and then started to decrease during the very wet run on low slopes $(\leq 3 \%)$ while it continued to increase for steeper slopes $(\geq 5 \%)$. This may be attributed to two factors. First, rainfall application on the soil surface during the dry and wet runs had eroded most of the detachable particles and thus had resulted in less sediment concentration. The reduction in sediment concentration in the very wet run was also associated with a reduction in the runoff rate. The other factor is that water
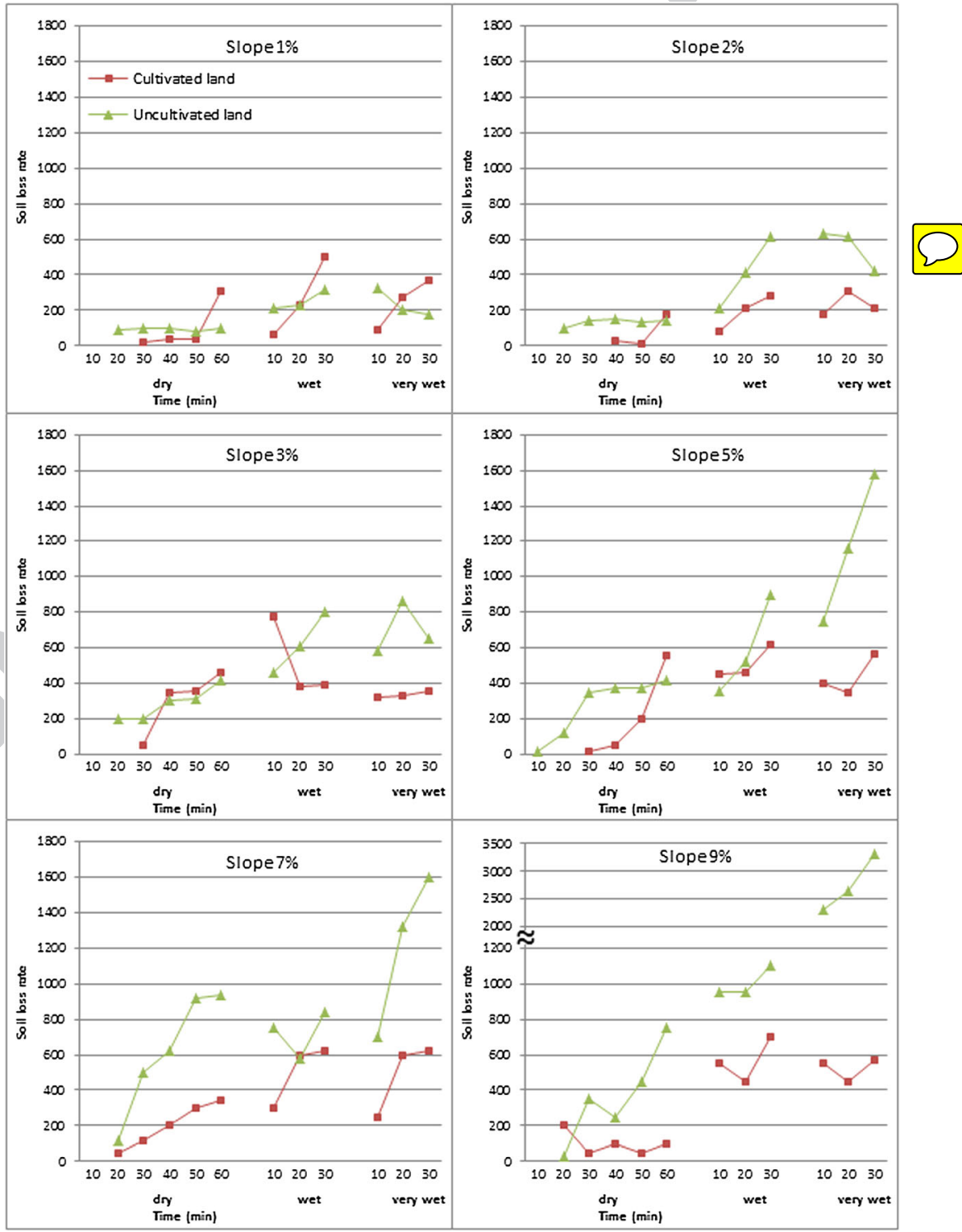

Figure 3. Soil loss rate $\left(\mathrm{mg} \mathrm{m}^{-2} \mathrm{~min}^{-1}\right)$ measured each $10 \mathrm{~min}$ under a rainfall intensity of $10 \mathrm{~mm} \mathrm{~h}^{-1}$. This figure is available in colour online at wileyonlinelibrary.com/journal/ldr. 
accumulation at the soil surface due to the low infiltration rate during the very wet run provided protection against raindrop impact and therefore reduced particle detachment. This effect is more obvious on low slopes compared with steeper slopes because of higher runoff at the latter and therefore less water accumulation at the soil surface. The rate of soil loss for the cultivated soils increased during the wet and very wet runs compared with the dry run. This is because the surface crust had developed on the cultivated soils during the dry and the wet runs. Therefore, the initial soil loss for cultivated land might be lower than uncultivated land, but after the crust formation started, the soil loss from cultivated land is increased. The dynamic changes in soil aggregate stability at various soil moisture contents and the impact on soil erosion and runoff could also explain these results (Cerdà, 1996; Cerdà, 1998; Mataix-Solera et al., 2011).

\section{CONCLUSIONS}

This research indicated that simple explanation of the erosion processes in the dry region is not possible because of the high variability of factors contributing to runoff and soil losses. The investigations indicated variable effects of rainfall intensity, slope, antecedent soil moisture, land use and length of rainfall event. Rainfall intensity was the most important factor affecting soil erosion under simulated rainfall. Erosion started at a low intensity and increased substantially as a result of small increment in rainfall intensity. Soil erosion is influenced by the formation of surface crust in this arid region. Soil erosion during the wet and very wet runs increased as the antecedent soil moisture content increased.

Soil and water losses from uncultivated land were higher than from cultivated land at the beginning of the rainfall events. This is due to the initially higher porosity and surface roughness of the cultivated soils. However, the rate of soil loss increased for the cultivated land during the very wet run because of the progressive crust formation and the changes in soil surface roughness. The results indicated that successive rainfall events within a short period, even with low rainfall intensity, enhance the formation of a surface crust and therefore generate high runoff and soil loss, especially on cultivated land. Therefore, protecting the soil surface from rain drop impacts to avoid crust formation, especially on steep slopes, is a key to soil conservation in these arid soils.

\section{REFERENCES}

Abrahams AD, Li G, Parsons AJ. 1996. Rill hydraulics on a semiarid hillslope, southern Arizona. Earth Surface Processes and Landforms 21: 35-47.

Abu Hammad A, Tumeizi A. 2012. Land degradation: socioeconomic and environmental causes and consequences in the eastern Mediterranean. Land Degradation \& Development 23: 216-226.

Ali A, Yazar A, Abdul Aal A, Oweis T, Hayek P. 2010. Micro-catchment water harvesting potential of an arid environment. Agricultural Water Management 98: 96-104.
Asadi H, Raeisvandi A, Rabiei B, Ghadiri H. 2012. Effect of land use and topography on soil properties and agronomic productivity on calcareous soils of a semiarid region, Iran. Land Degradation \& Development 23: 496-504. DOI: 10.1002/ldr.1081

Barbera V, Poma I, Gristina L, Novara A, Egli M. 2012. Long-term cropping systems and tillage management effects on soil organic carbon stock and steady state level of $\mathrm{C}$ sequestration rates in a semiarid environment. Land Degradation \& Development 23: 82-91.

Bisaro A, Kirk M, Zdruli P, Zimmermann W. 2013. Global drivers setting desertification research priorities: insights from a stakeholder consultation forum. Land Degradation \& Development. Accepted manuscript online: DOI: 10.1002/ldr.2220.

Bradford JM, Ferris JE, Remely PA. 1987. Interrill soil erosion processes: I. Effect of surface sealing on infiltration, runoff, and erosion splash detachment. Soil Science Society of America Journal 51: 1566-1571.

Cerdà A. 1996. Soil aggregate stability in three Mediterranean environments. Soil Technology 9: 133-140.

Cerdà A. 1998. Soil aggregate stability under different Mediterranean vegetation types. Catena 32: 73-86.

Cerdà A. 1999. Parent material and vegetation affect soil erosion in eastern Spain. Soil Science Society of America Journal 63: 362-368.

Cerdà A. 2000. Aggregate stability against water forces under different climates on agriculture land and scrubland in southern Bolivia. Soil and Tillage Research 36: 1-8.

Cerdà A. 2002. The effect of season and parent material on water erosion on highly eroded soils in eastern Spain. Journal of Arid Environments 52: 319-337.

Cerdà A, Doerr S. 2007. Soil wettability, runoff and erodibility of major dry-Mediterranean land use types on calcareous soils. Hydrological Processes 21: 2325-2336.

De Luis M, González-Hidalgo JC, Longares LA. 2010. Is rainfall erosivity increasing in the Mediterranean Iberian Peninsula? Land Degradation \& Development 21: 139-144.

Defersha MB, Melesse AM. 2012. Effect of rainfall intensity, slope and antecedent moisture content on sediment concentration and sediment enrichment ratio. Catena 90: 47-52.

Esteves M, Planchon O, Lapetite JM, Silveira N, Cadet P. 2000. The 'EMIRE' large rainfall simulator: design and field testing. Earth Surface Processes and Landforms 25: 681-690.

Fu S, Liu B, Liu H, Xu L. 2011. The effect of slope on interrill erosion at short slopes. Catena 84: 29-34.

Gabarrón-Galeote MA, Martínez-Murillo JF, Ruiz-Sinoga JD. 2012. Relevant effects of vegetal cover and litter on the soil hydrological response of two contrasting Mediterranean hillslopes at the end of the dry season (south of Spain). Hydrological Processes 26: 1729-1738.

García-Orenes F, Cerdà A, Mataix-Solera J, Guerrero C, Bodí MB, Arcenegui V, Zornoza R, Sempere JG. 2009. Effects of agricultural management on surface soil properties and soil-water losses in eastern Spain. Soil and Tillage Research 106: 117-123.

García-Orenes F, Guerrero C, Roldán A, Mataix-Solera J, Cerdà A, Campoy M, Zornoza R, Bárcenas G, Caravaca F. 2010. Soil microbial biomass and activity under different agricultural management systems in a semiarid Mediterranean agroecosystem. Soil and Tillage Research 109: 110-115. DOI: 10.1016/j.still.2010.05.005

García-Orenes F, Roldán A, Mataix-Solera J, Cerdà A, Campoy M, Arcenegui V, Caravaca F. 2012. Soil structural stability and erosion rates influenced by agricultural management practices in a semi-arid Mediterranean agro-ecosystem. Soil Use and Management 28: 571-579. DOI: $10.1111 / \mathrm{j} .1475-2743.2012 .00451 . x$

Gardner WH. 1986. Water content. In Methods of soil analysis. Part I: physical and mineralogical methods, (2 ${ }^{\text {nd }}$ edn). Klute A (ed.). American Society of Agronomy-Soil Science Society of America: Madison, WI; 493-545.

Giménez-Morera A, Ruiz Sinoga JD, Cerdà A. 2010. The impact of cotton geotextiles on soil and water losses from Mediterranean rainfed agricultural land. Land Degradation \& Development 21: 210-217.

Greer JD. 1971. Effect of excessive rate rainstorms on erosion. Journal of Soil and Water Conservation 24: 196-197.

Kocyigit R, Demirci S. 2012. Long-term changes of aggregate-associated and labile soil organic carbon and nitrogen after conversion from forest to grassland and cropland in northern Turkey. Land Degradation \& Development 23: 475-482.

Li XY, Contreras S, Sole-Benet A, Canton Y, Domingo F, Lazaro R, Lin H, Wesemael BV, Puigdefabregas J. 2011. Controls of infiltration-runoff processes in Mediterranean karst rangelands in SE Spain. Catena 86: 98-109. 
Mah MGC, Douglas LA, Ringrose-Voase AJ. 1992. Effects of crust development and surface slope on erosion by rainfall. Soil Science 154: 37-43.

Martínez-Murillo JF, Ruiz-Sinoga JD. 2007. Seasonal changes in the hydrological and erosional response of a hillslope under dryMediterranean climatic conditions (Montes de Málaga, South of Spain). Geomorphology 88: 69-83.

Martínez-Murillo JF, Ruiz-Sinoga JD. 2010. Water repellency as run-off and soil detachment controlling factor in a dry-Mediterranean hillslope (South of Spain). Hydrological Processes 24: 2137-2142.

Martínez-Murillo JF, Nadal-Romero E, Regüés D, Cerdà A, Poesen J. 2013. Soil erosion and hydrology of the western Mediterranean badlands throughout rainfall simulation experiments: a review. Catena 106: 101-112.

Mataix-Solera J, Cerdà A, Arcenegui V, Jordán A, Zavala LM. 2011. Fire effects on soil aggregation: a review. Earth-Science Reviews 109: 44-60.

Morin J, Goldberg D, Seginer I. 1967. A rainfall simulator with a rotating disk. Transactions of the American Society of Agricultural and Biological Engineers 10: 74-79.

Murphree CE, Mutchler CK. 1981. Verification of the slope factor in the universal soil loss equation for low slopes. Journal of Soil and Water Conservation 34: 300-302.

Mutchler CK, Hermsmeier LF. 1965. A review of rainfall simulators. Transactions of the American Society of Agricultural and Biological Engineers 8: 67-68.

Peng T, Wang S. 2012. Effects of land use, land cover and rainfall regimes on the surface runoff and soil loss on karst slopes in southwest China. Catena 90: 53-62.

Pérez-Latorre FJ, Castro L, Delgado A. 2010. A comparison of two variable intensity rainfall simulators for runoff studies. Soil and Tillage Research 107: 11-16.

Quansah C. 1981. The effect of soil type, slope, rain intensity and their interactions on splash detachment and transport. Journal of Soil Science 32: $215-224$.

Ramos MC, Martínez-Casasnovas JA. 2010. Effects of field reorganisation on the spatial variability of runoff and erosion rates in vineyards of Northeastern Spain. Land Degradation \& Development 21: 1-12.

Ruiz Sinoga JD, Garcia Marín R, Martínez-Murillo JF, Gabarrón Galeote MA. 2010. Pluviometric gradient incidence and the hydrological behaviour of soil surface components (southern Spain). Land Degradation \& Development 21: 484-495.

Salameh E, Remawi O, Bannayan H. 1991. Groundwater artificial recharge in Jordan. Water Research and Study Center, University of Jordan: Amman, Jordan.
Schindewolf M, Schmidt J. 2012. Parameterization of the EROSION 2D/ 3D soil erosion model using a small-scale rainfall simulator and upstream runoff simulation. Catena 91: 47-55.

Serrano-Muela MP, Nadal-Romero E, Lana-Renault N, González-Hidalgo JC, López-Moreno JI, Beguería S, Sanjuan Y, García-Ruiz JM. 2013. An exceptional rainfall event in the central western pyrenees: spatial patterns in discharge and impact. Land Degradation \& Development. Accepted manuscript online: DOI: 10.1002/ldr.2221.

Singer MJ, Blackard J. 1982. Slope angle-interrill soil loss relationships for slopes up to 50\%. Soil Science Society of America Journal 46: 1270-1273.

Singer MJ, Janitzky P, Blackard J. 1982. The influence of exchangeable sodium percentage on soil erodibility. Soil Science Society of America Journal 46: 117-121.

Stavi I, Lal R, Jones S, Reeder RC. 2012. Implications of cover crops for soil quality and geodiversity in a humid-temperate region in the Midwestern USA. Land Degradation \& Development 23: 322-330.

Steel R, Torrie J, Dickey D. 1996. Principles and procedures of statistics: a biometrical approach. ( $3^{\text {rd }}$ edn). McGraw-Hill: New York, NY.

Taimeh AY. 1989. Soils of Muwaqqar. University of Jordan: Amman, Jordan.

Truman CC, Potter TL, Nuti RC, Franklin DH, Bosch DD. 2011. Antecedent water content effects on runoff and sediment yields from two Coastal Plain Ultisols. Agricultural Water Management 98: 1189-1196.

Vermang J, Demeyer V, Cornelis WM, Gabriels D. 2009. Aggregate stability and erosion response to antecedent water content of a loess soil Soil Science Society of America Journal 73: 718-726.

Wang Q, Wang S, Yu X. 2011. Decline of soil fertility during fores conversion of secondary forest to Chinese fir plantations in subtropical China. Land Degradation \& Development 22: 444-452.

Wischmeier WH, Smith DD. 1978. Predicting rainfall erosion losses: a guide to conservation planning. US Department of Agriculture: Washington, DC.

Yimer F, Abdelkadir A. 2011. Soil property changes following conversion of acacia woodland into grazing and farmlands in the Rift Valley area of Ethiopia. Land Degradation \& Development 22: 425-431.

Young RA, Burwell RE. 1972. Prediction of runoff and erosion from natural rainfall using a rainfall simulator. Soil Science Society of America Proceedings 36: 827-830.

Ziadat FM. 1995. Effect of management practices on soil losses in arid to semi-arid area in Jordan. M.Sc. thesis, University of Jordan: Amman, Jordan. 


\section{Author Query Form}

\section{Journal: Land Degradation \& Development}

\section{Article: ldr_2239}

Dear Author,

During the copyediting of your paper, the following queries arose. Please respond to these by annotating your proofs with the necessary changes/additions.

- If you intend to annotate your proof electronically, please refer to the E-annotation guidelines.

- If you intend to annotate your proof by means of hard-copy mark-up, please refer to the proof mark-up symbols guidelines. If manually writing corrections on your proof and returning it by fax, do not write too close to the edge of the paper. Please remember that illegible mark-ups may delay publication.

Whether you opt for hard-copy or electronic annotation of your proofs, we recommend that you provide additional clarification of answers to queries by entering your answers on the query sheet, in addition to the text mark-up.

\begin{tabular}{|c|l|c|}
\hline Query No. & \multicolumn{1}{|c|}{ Query } & Remark \\
\hline Q1 & $\begin{array}{l}\text { AUTHOR: Journal style requires that the first forenames of all authors should be given. } \\
\text { Please provide missing details. }\end{array}$ & \\
\hline Q2 & AUTHOR: In Tables 1-3, please provide the significance of the asterisk symbol. & \\
\hline Q3 & AUTHOR: Please provide the significance of the asterisk symbols (***) here. & \\
\hline
\end{tabular}


Required software to e-Annotate PDFs: Adobe Acrobat Professional or Adobe Reader (version 7.0 or above). (Note that this document uses screenshots from Adobe Reader $\mathrm{X}$ )

The latest version of Acrobat Reader can be downloaded for free at: http://get.adobe.com/uk/reader/

Once you have Acrobat Reader open on your computer, click on the Comment tab at the right of the toolbar:

닙

This will open up a panel down the right side of the document. The majority of tools you will use for annotating your proof will be in the Annotations section, pictured opposite. We've picked out some of these tools below:

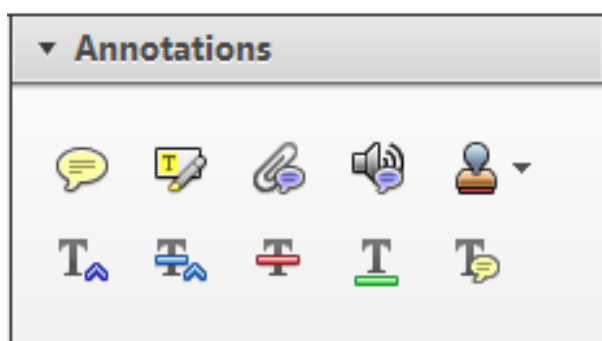

1. Replace (Ins) Tool - for replacing text.

Strikes a line through text and opens up a text box where replacement text can be entered.

How to use it

- Highlight a word or sentence.

- Click on the Replace (Ins) icon in the Annotations section.

- Type the replacement text into the blue box that appears.

Idard tramework for the analysis of $\mathrm{m}$ icy-Nevertheless, it also led to exog،

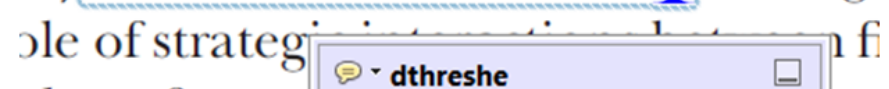
\begin{tabular}{l|l|l} 
aber of comp & 08/06/2011 15:58:17 & 0
\end{tabular} is that the $\mathrm{s} 1 \overline{\text {, which led }}$ of nain compo: be level, are exc nc

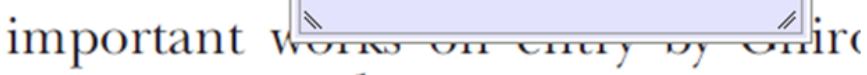
M heneferth) ${ }^{1}$ we anen the "hlarl $\mathrm{h}$

3. Add note to text Tool - for highlighting a section to be changed to bold or italic.

T Highlights text in yellow and opens up a text box where comments can be entered.

How to use it

- Highlight the relevant section of text.

- Click on the Add note to text icon in the Annotations section.

- Type instruction on what should be changed regarding the text into the yellow box that appears.

namic responses of mark ups ent with the VAR evidence

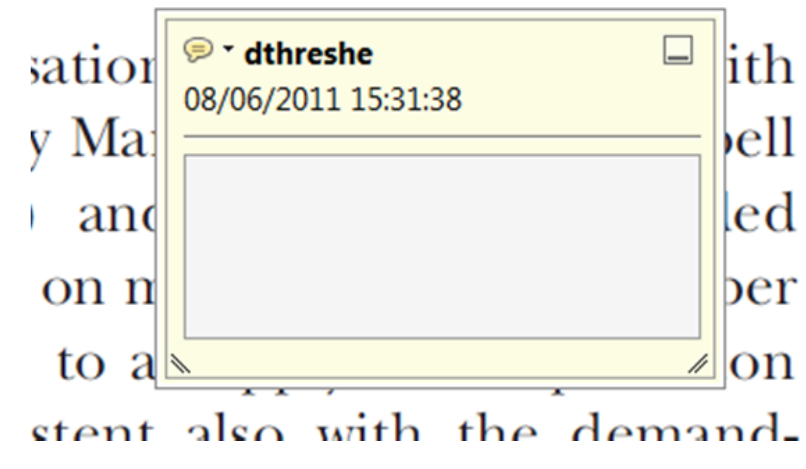

2. Strikethrough (Del) Tool - for deleting text.

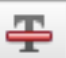

Strikes a red line through text that is to be deleted.

How to use it

- Highlight a word or sentence.

- Click on the Strikethrough (Del) icon in the Annotations section.

there is no room tor extra prohts al s ups are zero and the number of ret) values are not determined by Blanchard and Kiyotaki (1987), sfect competition in general equilil ts of aggregate demand and supply lassical framework assuming monol sen an evorenous number of firms

4. Add sticky note Tool - for making notes at specific points in the text.

Marks a point in the proof where a comment needs to be highlighted.

How to use it

- Click on the Add sticky note icon in the Annotations section.

- Click at the point in the proof where the comment should be inserted.

- Type the comment into the yellow box that appears.

iaisu airu suppiy sisuks. hivsl ui

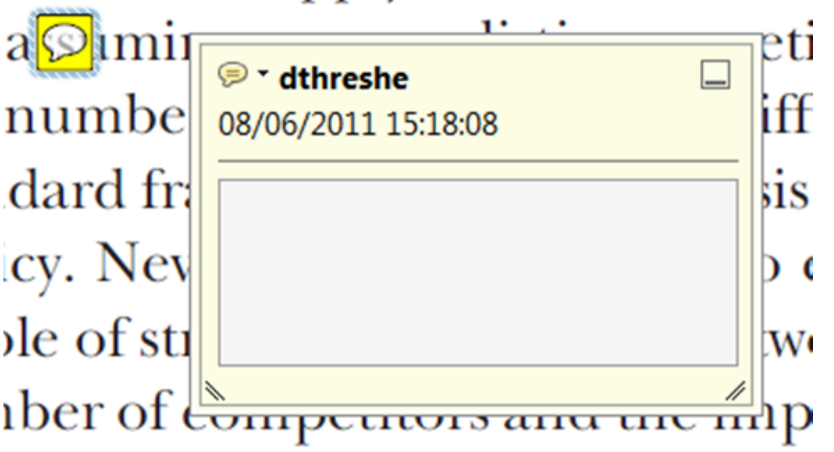

is that the structure of the sectc. 
5. Attach File Tool - for inserting large amounts of text or replacement figures.

Inserts an icon linking to the attached file in the appropriate pace in the text.

How to use it

- $\quad$ Click on the Attach File icon in the Annotations section.

- Click on the proof to where you'd like the attached file to be linked.

- Select the file to be attached from your computer or network.

- Select the colour and type of icon that will appear in the proof. Click OK.

E N D

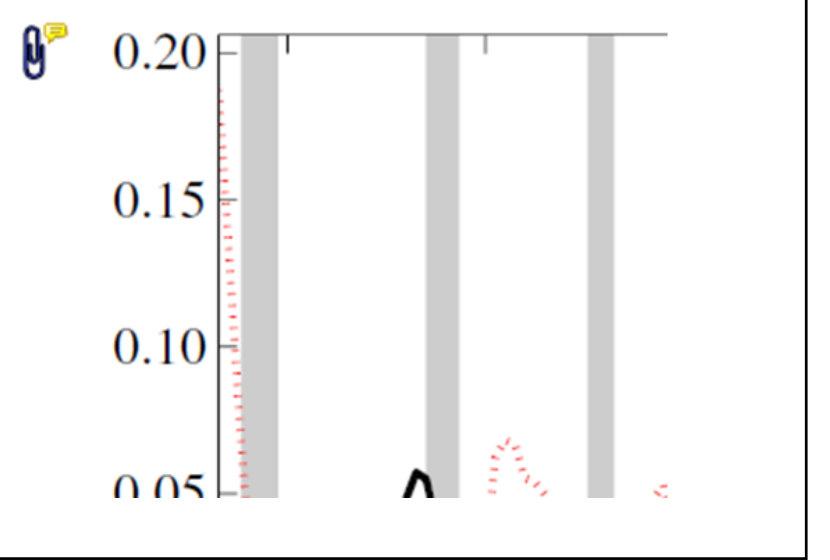

6. Add stamp Tool - for approving a proof if no corrections are required.

- Inserts a selected stamp onto an appropriate place in the proof.

\section{How to use it}

- $\quad$ Click on the Add stamp icon in the Annotations section.

- Select the stamp you want to use. (The Approved stamp is usually available directly in the menu that appears).

- Click on the proof where you'd like the stamp to appear. (Where a proof is to be approved as it is, this would normally be on the first page).

)t the Dusiness cycie, starting with the on perfect competition, constant ret

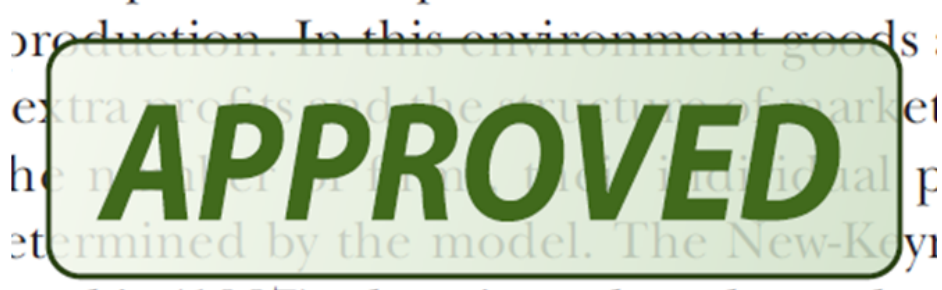
otaki (1987), has introduced produc general equilibrium models with nomin:

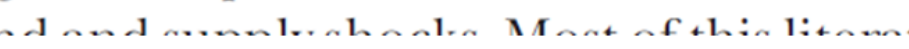

- Drawing Markups

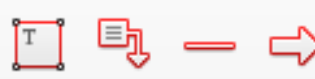

$0 \bigcirc \sqrt{6} \otimes$

\section{How to use it}

- Click on one of the shapes in the Drawing Markups section.

- Click on the proof at the relevant point and draw the selected shape with the cursor.

- To add a comment to the drawn shape, move the cursor over the shape until an arrowhead appears.

- Double click on the shape and type any text in the red box that appears.
7. Drawing Markups Tools - for drawing shapes, lines and freeform annotations on proofs and commenting on these marks.

Allows shapes, lines and freeform annotations to be drawn on proofs and for comment to be made on these marks.

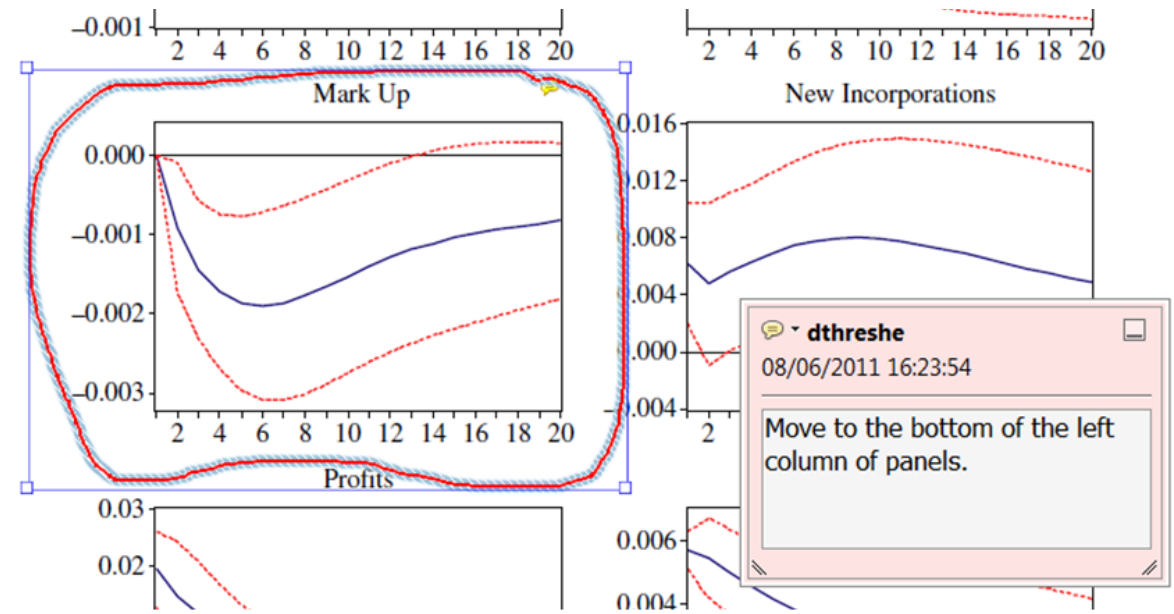

For further information on how to annotate proofs, click on the Help menu to reveal a list of further options:

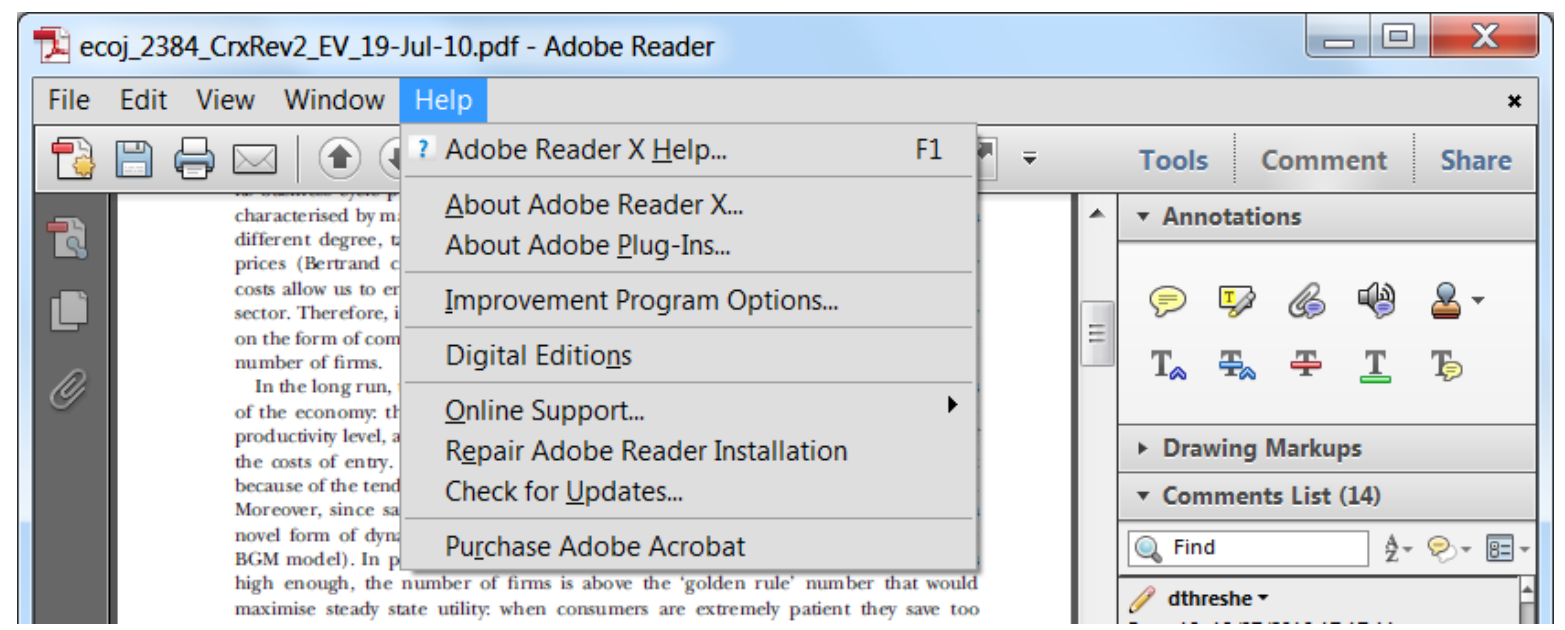

